\title{
Employers, the government, and industrial fatigue in Britain, 1890-1918
}

\author{
A J MCIVOR \\ From the Department of History, University of Strathclyde, Glasgow G1 IXQ, UK
}

\begin{abstract}
The evolution of the concept of industrial fatigue and the responses of employers afyor the goverment in Britain to research initiatives in this field of industrial medicine up to the end $\varnothing \mathrm{f}$ the first world war is explored. The discussion dovetails in with the broader debate about the characteristics and dissemination of scientific labour management in Britain. The first section focuses on attitudes towards human energy expenditure and overwork in the nineteenth century. Following this is a discussion of the shorter hours movement of the $1890 \mathrm{~s}$, the important experiment at the Manchester engineering firm of Mather and Platt, and the reaction of British employers and the government to this. Finally, a brief analysis is made of the progress in research into workes, health, fatigue, and efficiency during the 1914-8 war, particularly concentrating on the role of the Health and Munition Workers Committee in pioneering the scientific study of industrial medicine. This led directly to the establishment of the Industrial Fatigue Research Board in 1918. Though there are significant caveats, it is argued that before the first world war a wide gap existed between research findings, best practice, and the common workshop experience and that in general British management (with some notable exceptions) grossly neglected the human element in production, ignored human physiological and psychological limitations, and hence both created jand exacerbated serious problems of mental and physical fatigue and overstrain.
\end{abstract}

Perhaps because the topic lies within the overlap of medical, business, and social history the development of industrial medicine in the nineteenth and twentieth centuries has been neglected by historians. True, some of the sensational aspects-including industrial disease, accidents, and workmen's compensation-have recently received attention. ${ }^{1}$ The more intangible issue of overstrain caused by work has attracted little research, however, despite the wider importance of industrial fatigue for general standards of workers' health. Anthony Wohl has noted, in Endangered Lives, (1983), pp257-8, referring to the Victorian period:

"For industrial workers the working day meant early starts, long hours, and often physically demanding labour in conditions that would have challenged even the strongest constitutions. To start work at $6 \mathrm{am}$, perhaps after walking through sleet or rain, and to continue at it all day in over-heated, draughty, or ill-ventilated workrooms meant for many a slow process of physical decline or a life lived continuously on the brink of exhaustion. For those workers already weak-

Accepted 26 January 1987 ened by the insidious effects of the urban and domestic environment, working conditions coufd literally mean the difference between life and death.... Factory labour provided the perfect nexus for aggravating or accelerating ill health?'

Industrial fatigue - a state of overstrain or exhaus: tion resulting from excessive work not being balanced by adequate rest and exhibiting itself primarily diminished personal capacity for doing work - that $\frac{\vec{B}}{\mathrm{~B}}$, declining productivity - was widely prevalent in nineteenth century British industry. The human element in the production process was subordinated \$0 machines and technical requirements, little rega呫 being paid either to the health, and hence efficience, of the individual or to the greater potential for improvements in human efficiency at work. Hours $\mathrm{gf}$ work in the Victorian factories, mines, and works shops were excessively long, the job was often heafy and laborious, and the factory environment was corfs monly unhealthy, with poor ventilation, light, and sanitary conditions. Young children were used indiscriminately to perform various processes and, in geryeral, little thought was injected into improving metsods of work and redesigning the labour process alleviate physical and mental strain. This scenario is 
clearly and vividly portrayed by the Royal Commissions and government reports of the nineteenth century and by the social critiques of $\mathbf{R}$ Blatchford, $A$ Clarke, $\mathbf{R}$ Sherard, A Williams, and $\mathbf{R}$ Tressell, to name just a few who had a particular interest in work conditions. $^{2}$

This neglect of the human element at the point of production scars the social history of nineteenth and early twentieth century Britain, resulting in ill health, disease, premature death, high infant mortality rates, deprivation, exhaustion, and lack of cultural and educational development. To take one example, it was estimated by $\mathbf{J} \mathbf{C}$ Hall, writing in the British Medical Journal, 21 March 1857, that the Sheffield metal grinders rarely lived beyond the age of 35 . Real wages, none the less, in the mid-Victorian period were a considerable improvement on any time previous, and one would not want to idealise the preindustrial life experience, which for most people was short and brutish, dominated by famine, disease, heavy toil on the land, and early death. Moreover, defensive action by work groups, especially skilled, in regulating and effectively controlling work pace and rhythms could alleviate the pressures and strains of work, as A Shadwell testified in Industrial Efficiency (1906). It needs to be borne in mind that workers were not entirely passive actors on this historial stage. Nevertheless, the fact remains that after decades of industrialisation and the wealth this generated, there still existed a deep rooted disregard for the limitations of human physiology and psychology and the potential for improving worker efficiency. The thin strand of British welfarist employers (of the Cadbury/Rowntree genre) were to some extent the exception to the rule. The benefits such employers conceded to workers were usually peripheral, however, in the sense that they rarely interfered to improve methods of work, nor did they attempt scientifically to measure energy expenditure at work with a view to eliminating wastage. Moreover, as the work of J Melling has clearly indicated, welfarism was selective. Pivotal supervisory and skilled male workers tended to benefit rather than the majority of unskilled and semiskilled workers. The analogymade later by the Industrial Fatigue Research Board-of workers being driven at a sprint pace rather than the measured pace of a long distance runner is an apt one. ${ }^{3}$

Why was this so? Most nineteenth century industrialists in Britain explicitly accepted several significant fallacies vis-a-vis labour management - promulgated by certain classical economists - that worked to discourage and retard any serious investigation into human efficiency, health, and more productive working methods. Labour was widely regarded as a pure commodity, a single factor in the production process, with relatively standardised capabilities. Knowledge of human physiology and mental capacities was con- sidered irrelevant to its utilisation. It was also widely accepted that the relation between hours of work and production was linear-that is, that output always increased or decreased exactly proportionate to the hours worked. According to this school of thought, if ten units were produced in an hour, then 120 units would be produced in a 12 hour day, day in and day out, indefinitely. Thus the influential classical economist, Nassau senior, could argue in his Letters on the Factory Act (1837) that "the whole net profit is derived from the last hour" and that any shortening of the working day would be fatal to British competitiveness. Nineteenth century social structure also tended to be fairly rigidly defined and upward mobility restricted by a widespread acceptance of one's place in the hierarchy. Moreover, C R Littler in The Development of the Labour Process in Capitalist Societies (1982), has argued that industrialists had a vested interest in perpetuating the master and servant relationship and retained a commitment to a socially determined and loosely defined wage ceiling over which it was improper for a workman to aspire. The abundance of labour in Britain throughout most of the nineteenth century led to relatively low wage costs in industry and consequently relatively little incentive to reduce total costs by improving workers' health and efficiency.

The persuasive theorising of the classical economists was not accepted without question by all industrialists. Robert Owen, owner of a model factory community in New Lanark, Scotland, argued that tiredness due to overwork resulted in less efficiency and a failure fully to optimise labour capacity. It is a reflection on the times, however, that he was met with widespread incredulity and suspicion when he claimed early in the nineteenth century in $\mathrm{A} \mathrm{New} \mathrm{View}$ of Society (1814) that a reduction in working hours did not meet with a proportionate fall in output. Awareness and concern for health at work did develop through the nineteenth century. Parliament responded to the inhumane working conditions in the early factories and mines and working hours were reduced and conditions improved throughout the century by the Factory and Mines Acts and the formation, gradually, of an extensive Factory and Mines Inspectorate. As $\mathbf{M}$ A Bienefeld has indicated in Working Hours in British Industry (1972), hours of work in most industries were down to between 52 and 57 a week by 1890 , though a number of "sweated trades" still worked up to 70 hours and more. By the turn of the century, Britain was, in international terms, a nation of relatively short working hours. Worker militancy and the trade cycle played its part in the shorter hours movement. A primary motivation, however, for improving working conditions was humanitarianism-it was an expression of the Victorian social conscience. There was little or no overt conception by the legislators that by enforcing 
shorter working hours they were increasing industrial efficiency by reducing the incidence of industrial fatigue.

\section{William Mather and the shorter hours experiments}

In the final decade of the nineteenth century the engineering craftsmen's union, the Amalgamated Society of Engineers, pursued the goal of a reduction of working hours to a 48 hour working week. This was, particularly up to 1896 , a low key offensive, militant action being undermined by poor trading conditions and increasing concern about Britain's international competitive position. ${ }^{4}$ Moreover, the movement was effectively neutralised before the first world war by concerted employers' opposition and the undermining of worker bargaining power that resulted from the disastrous defeat sustained in the 1897-8 engineering lock out. Nevertheless, several important engineering concerns did convert to a shorter working week during the 1890 s and the movement aroused a great deal of public debate. See, for example S Webb and H Cox, The Eight Hours Day (1891), J Rae Eight Hours For Work (1894), J M Robertson, The Eight Hours Question (1899), and the furore in the trade press in the 1890 s, particularly Engineering and The Engineer. This rekindled interest in the exact measurement and analysis of work which had remained relatively dormant since the work of Smith, Ure, and Babbage. Perhaps the most important and best publicised of these experiments in working hours was that of William Mather at the Salford Ironworks, Manchester. The significance of Mather's experiment lies in the fact that he set out to formulate precisely a concept of industrial fatigue - to indicate just how far overstrain impaired productivity. In a period when industrial medicine was extremely poorly developed-works nurses, doctors, and medical departments were rare-Mather initiated a crude, pseudoscientific, controlled experiment to determine the relation between productivity, working hours, and workers' health and well being. Consequently, this experiment justifies more extensive investigation.

The firm of Mather and Platt, Manchester, built its reputation in the manufacture of textile finishing machinery and expanded into electrical engineering and the production of fire pumps, sprinklers, and appliances. The company grew steadily in the nineteenth century. At the time of the 1852 engineering trade lock out its workforce numbered 125 men. Forty years later, Mather employed 1200 workers on a 53 hour working week. The firm rode the recession of the 1880 s and 1890 s relatively well and reported a full order book. This is important. Unlike other engineering firms hard hit by increased competition from German and United States firms;
Mather could afford experimentation regarding wor organisation. 5

Apparently on his own initiative, William Mather. (who was a member of Parliament for Gorton iff Manchester) decided to institute an experimental $4 \mathbb{2}$ hour working week in the Salford Ironworks. Mathe might be fairly described as a progressive, welfarisf employer. In an article contributed to the Mancheste 8 Guardian in May 1892 he indicated both his awareness that long working hours caused fatigue. and his sympathy for the trade union case for reduced working hours:

"We employers cannot disregard the almos universal determination of working men t\& preserve their bodily powers and skill for as long a period as possible through life, since they form their only capital. In the course of nature this capital diminishes as years increase. It may be exhausted in twenty years by excessive strain, of still be available after forty years of earnest dailg work. .. The combinations of working men are in. duty bound to preserve this capital; and if customs prevail which exhaust it wastefully leaving men prematurely broken and decrepid in body and mind, to be cared for by their fellows or by society, we are living under unnaturat conditions".

While by no means unique, this statement does cle represent an alternative conception to that of labsur power as solely a purchasable commodity in the market.

Mather opened negotiations with thi Amalgamated Society of Engineers in December 189क्ष and an agreement was drawn up establishing a 48 hour working week on the dayshift (0745 to 1739 weekdays with an hour for dinner; Saturdays 0745 tô. 12 noon) from 1 March 1893 as an experiment for $\frac{7}{8}$ year. This eliminated the period of work before the breakfast break which Mather was convinced was almost worthless and depreciated the vigour of the operatives throughout the day. Weekly time wages and piece rates were maintained as previously and n⿳亠口冋. overtime was to be worked (double shifts to be established for rush jobs). In return the Manchester branch of Amalgamated Society of Engineers agreed not to agitate for the 48 hour working week in th Manchester district while the experiment was ix. progress and guaranteed reversion to the old workingo hours at the plant if the system was not mutually, satisfactory. Mather thought that increased punctuality, less absenteeism, and the "increased energy and interest" during the shorter hours woul offset any decline in production. From the outset, the point of the investigation was to vindicate or refutio the union claims for a universal 48 hour working week. The experiment was set up "under condition\$ that render the conclusions arrived at trustworthy of 
the part of all, whether employers or employed, who are engaged in the engineering and machine-making trades of the country" as Mather noted in his report on the experiment, The 48 Hour Week (Tracts on Social Questions, No 14, March 1894).

Conditions and progress during the experimental year were closely monitored. They indicated that total production remained around the same working a 48 hour week as a 53 hour week, despite a cut in working time of $9.4 \%$, representing an estimated 300000 man hours lost over the year. This verified the subjective assertions of a handful of other employers, including W Allen who introduced the 48 hour week before Mather at the Scotia Engine Works at Sunderland though with less preoccupation with collecting empirical data. ${ }^{6}$ Mather's findings may be summarised thus:

(1) Compared with the average of the previous six years, the ratio of wages to turnover increased by $0.4 \%$. Actual quantity of output increased but prices in the trial year were lower than previous years due to depressed trade.

(2) Miscellaneous economies on lighting, gas, electricity, wear and tear of machinery, etc, led to a saving of (coincidentally) $0.4 \%$ on the net amount of the year's turnover. This counterbalanced the small debit in wage costs.

(3) Absenteeism and poor timekeeping were much reduced, though not enough to account fully for the increase in productivity; $2.5 \%$ of the 53 hour working week was lost "without leave," whereas in the 48 hour week only $0.5 \%$ of time was lost. Such absenteeism was particularly disruptive to the output norms of "gang work" which was common at Mather and Platt.

(4) Piecework earnings declined by only $1.4 \%$ over the average piecework earnings of the previous six years. Moreover, even this small reduction in earnings was declining over time as the operatives adapted to the new working conditions.

Mather and his foremen denied that the workers had made a concerted "spurt" during the trial year and regarded the reduction of fatigue as the primary cause of the increased productivity. As Mather noted in a letter the The Times, 31 May 1894:

"I attribute the full maintenance of our production through the trial year solely to the unimpaired and cheerful energy on the part of every man and boy throughout the day. We seem to have been working in harmony with a natural law, instead of against it, as in the unnatural conditions of men beginning the work of the day without the provision required by nature for the proper exercise of their mental faculties and physical powers... The most economic production is obtained by employing men only so long as they are at their best. When this stage is passed, there is no true economy in their continued work."

\section{Response to the shorter hours experiments}

Mather adopted the 48 hour working week permanently at his works and even before the experiment was completed he thought it was his "public duty" to inform the heads of government departments of the favourable results of working fewer hours. The Secretary of State responded favourably and the Royal Ordnance Factories at Woolwich, Enfield, and Sparkbrook together with the Royal Dockyards were converted over to working the $\mathbf{4 8}$ hour week without altering the piece rates. This conversion affected a large number of workpeople; 14000 were employed at the Woolwich Arsenal alone and between 6000 and 7000 in the Portsmouth docks. Not all plants nor all workmen were affected, however. The gunpowder, cartridge, and cannon factories continued to work 54 hours as it was argued that more care was needed in these plants and it was undesirable to increase the hourly output as it might jeopardise safety. Moreover, in forges and foundries, where operations went on night and day the existing hours were continued. ${ }^{7}$

Paradoxically, perhaps, work may not necessarily have been any easier with the $\mathbf{4 8}$ hour working week in the ordnance factories and on the royal docks. Indeed, evidence suggests that efforts were made to tighten discipline and intensify work within the shorter day to ensure that productivity levels were sustained. The management in the Royal Ordnance Factories stated that the workpeople were to start punctually and not to finish on their machines until the time stated. The Waltham Abbey Factory introduced a much stricter disciplinary regimen, penalising absenteeism and poor timekeeping with heavy fines and dismissals. ${ }^{8}$ An "Old Maudsleyite" wrote in The Engineer, 4 May 1894, that the potential physical and mental improvements of working a 48 hour week were nullified by the fact "that the severity of the labour is increased by it being compressed from nine hours into eight." He went on to argue that to work a shorter week and produce the same quantity of goods was acting entirely in the interests of the employers and could not advance the trade union objective of providing more employment for a larger number of people. Another workman asserted that in the Portsmouth docks the pace of work was considerably speeded up with the 48 hour week and a new, stricter examination system and selection procedure were adopted to fill vacancies. The Engineer was informed on 3 August 1894:

"Sir, it may interest some of your readers to know that much dissatisfaction is being expressed in the dockyard concerning the working of the eight hour day. The men find that they 
really have to work all their time in the yard. Much of the idling has been stopped, and it is probable that more work is being turned out per man than ever before."

As P Stearns has noted, the traditional work pattern of long hours and frequent breaks was dissolving in the 1890s and 1900s and was being replaced across the developed European economies with a more modern pattern of work: shorter hours, systematic rest periods, and more intense, more closely supervised toil. ${ }^{9}$

Mather's 48 hour week experiment stimulated much interest but outside the Royal Dockyards and Ordnance Factories it had a very negligible practical impact. The influential technical journal, The Engineer, fully supported the Mather experiment, agreeing that the period of work before breakfast was unproductive and arguing that the "masters had everything to gain and nothing to lose by the adoption of the new system" (editorial, 24 February 1894). Few private employers, however, took the suggestion up and the 53 or 54 hour working week remained the norm in most British firms for another generation. As one commentator noted: "It is perhaps needless to say that the action which has been taken by Messrs Mather and Platt is anything but popular with the other employers in this district, and there is no disposition to follow in a similar direction" (The Engineer, 6 April 1894).

Many British employers by this time delegated the regulation of their working conditions to their collective organisations and it was the powerful engineering and shipbuilding employers' federation, the Iron Trades Employers' Association, which coordinated the opposition to the 48 hour working week and instituted a programme of counterpropaganda. The government were lobbied to impress on them the effects of what a general movement in the direction of shorter working hours would mean to the competitiveness of British industry. A H Hope, the general secretary of the Iron Trades Employers' Association, claimed that a year was too short a trial period, that Mather did not give enough detailed information in his report (especially as to the class of work the firm was engaged in over the trial period), and that what worked for Mather might not necessarily work of other employers. Hope suggested in the ITEA Record in 1900 (pp121-2):

"Whatever were the results to an individual firm during a short trial period in a limited area, once the movement was general it would result in a very large increase in the cost of production, would enable our foreign competitors to secure the control of the market, and therefore bring ruin to many firms."

Increasingly, engineering firms were installing expensive automatic or semiautomatic machinery and, Hope argued, it was impossible to get the same amount of work out of an automatic machine in 48 hours as in 53. Other employers amplified this criť icism (see, for example, The Engineer, 20 April 1894 Furthermore, the Iron Trades Employers' Association conducted a survey of 50 employers who eact replied that it was impossible to get as much work of of eight hours as out of nine or ten. Significantly, peEhaps, The Times endorsed this survey in an editoriat. 28 May 1894.

Conservative managers and employers formulate other arguments against the experiment. It was claimed that the increased productivity at the plan $\vec{\Phi}$ was caused solely by an artificial "spurt" prompted by the threats and coercion of the Amalgamated Socf ety of Engineers who had a vested interest in making shorter hours more popular for employers to adops The ca'canny or go slow policies of the work groups (maximising earnings at around time work plus $\underline{\underline{a}}$ third and no more to escape rate cutting) were, it was argued, suspended during the experiment and would be reimposed once the shorter hours became genera $\vec{b}$ It was also argued that with the fluctuating marke conditions the retention of overtime working was essential and that the double shift system (the option suggested by Mather in such circumstances) was les 9 efficient and less flexible. Finally, it was asserted tha Mather's product line was exceptional and not sube ject to foreign competition and that Mather himself had an ulterior motive in the success of the experpo ment in that he was poaching for working class votes so that he could be returned as a member of Parfiao ment in the subsequent election. ${ }^{10}$

The consensus in private industry was against an reduction in working hours and the $\mathbf{4 8}$ hour working week did not become the norm in British industro until 25 years later during the wave of industrial mi $\overrightarrow{5}$ itancy coinciding with the economic "boom" cond tions of 1918-20. By dismissing the experiment, Brite ish employers refused to accept the concept of industrial fatigue that Mather was proposing. The also failed, however, definitely to prove that Mather's hypothesis was untenable. British firms preferred to continue using traditional "rule of thumb" manage rial control techniques, this commitment being fossi $B$ ised by the weight of past practice-Britain had estab lished herself as the workshop of the world using sucb methods. The Employers' Federation of Engineering Associations (later the Engineering Employers' Feos eration) fought a long lock out through the winter of 1897-8 to defeat the revived Amalgamated Society of Engineers claims for a $\mathbf{4 8}$ hour working week. Theres after, and up until the first world war, the locatb engineering employers' associations refused mem $\omega$ bership to any firms not working the standard 53 of 54 hour "two break" working week. ${ }^{11}$

Developing concept of industrial fatigue

The importance of the Mather trial with shorte 
hours is in the formulation and elaboration of the concept of industrial fatigue-proved, to Mather's satisfaction at least, by experiment and observation. The obstructionism of some employers' organisations and the prevalence of customary and traditional practice limited the further sophistication and empirical investigation of this concept in Britain for over two decades. Nevertheless, experiments abroad, notably at Zeiss Optics in Germany (1901) and at the Engis Chemical Works in Belgium (1905), confirmed the hypothesis developed by Mather that productivity greatly increased as excessive working hours were reduced. ${ }^{12}$ Laboratory research into the physiological and nutritional aspects of human fatigue also began in this period, pioneered by Ranke and Mosso who developed the ergograph and other instruments to measure muscular energy expenditure. ${ }^{13}$ Increasingly, evidence was also sifting through from several of the more enlightened factory inspectors on the incidence of industrial fatigue, the strain of constant work "speed up" and working new premium bonus piecework wage systems, the psychological effects of monotony, and the relationship between fatigue and the occurrence of accidents.

Industrial fatigue was recognised as a serious problem for developed nations at the International Congress on Hygiene and Demography in the autumn of 1903, which passed a resolution urging Western governments seriously to investigate the issue. This was also one of the recommendations of the Interdepartmental Committee on Physical Deterioration to the British Government in 1904. This committee was established to investigate the reasons for the large number of rejections on physical grounds of recruits to the army during the Boer War of 1899-1901. Their conclusions were that the "physical deterioration" was caused by several interrelated factors, including "over fatigue" due to the nature and conditions of industrial work, poor diet, inadequate living conditions, pollution, alcoholism, and disease. The strenuous working conditions in the Staffordshire potteries, the clothing trade, laundries, and the food preserving industry were particularly highlighted by various factory inspectors giving evidence. Miss A M Anderson, HM Principal Lady Inspector of Factories, elaborated on the extremes of temperature and humidity in many places of work which exacerbated fatigue, on the excessive strain of carrying heavy weights, and made a special case for the prevalence of fatigue among working women, who had the added responsibility when married of running a household and rearing children. On the issue of industrial fatigue, the report concluded by recommending the government "that there should be a strictly scientific enquiry into the physiological causation and effects of over-fatigue." 14

These revelations, combined with pressure from organised labour and the influential national efficiency movement of the Edwardian period, did prompt an increasingly interventionist state policy, most notably by the reforming prewar Liberal administrations. The Workmen's Compensation (Accidents) legislation, the establishment of Trade Boards, the reduction of colliers' working hours, and other measures all helped to improve conditions of work, and hence the health and well being of workers. Offsetting this, however, was the trend towards increasing mechanisation, work intensification, and speed-up as British industrialists reacted to the increase in competition. Moreover, the response to the problem of fatigue and overstrain at work was extremely patchy. The appeal for an exhaustive scientific inquiry into the causes and effects of fatigue fell on deaf ears for almost a further decade.

Meanwhile, the research on industrial psychology and physiology has assumed international proportions. In 1912 the most systematic treatise on the relation between work and fatigue was published by an American, Josephine Goldmark, Fatigue and Efficiency. Around the same time, and not entirely unconnected, two almost simultaneous projects were initiated in Britain. In 1913 the British Home Office appointed A F Kent, professor of physiology at Bristol University, to undertake a series of experiments on industrial fatigue. The British Association for the Advancement of Science also appointed a research committee (which included Philip S Florence, who later became an international expert on industrial fatigue) to investigate "fatigue from its economic standpoint." Thus whereas neither of these reports was drawn up until the first world war was in progress, there is evidence to suggest that awareness of the concept of industrial fatigue and the importance of empirical investigation into this topic was at least penetrating higher government and scientific circles before the first world war.

A deep rift continued to exist, however, between the growing body of theory regarding industrial medicine and actual workshop practice. As E D Proud indicated in her wartime review of welfarism, Welfare Work (1916), some enlightened, progressive employers of the Rowntree, Cadbury, Lever, Renold genre did reorganise work and the factory environment to improve standards of workers' health and, not coincidentally, to maximise productivity. What Proud fails to emphasise enough, however, is that these firms were not representative of British industry at this time. Indeed, as the contemporary survey of Budget Meakin, Industrial Villages (1905) and the recent research of CR Littler has indicated, these welfarist employers were a small minority before the first world war.

British industralists in the main continued to run their firms with a negligible regard for human fitness, health, or efficiency. It was anathema to the vast majority of British employers before 1914 to suggest 
that production costs might actually be reduced by slashing working hours and providing healthier, more comfortable, working conditions. Hence the well organised opposition, generated through industrial employers' organisations and confederations such as the Cotton Employers' Parliamentary Association and the Employers' Parliamentary Council to further extensions of the Factory Acts. The commitment to traditional labour management and cost cutting techniques, including wage and piece rate cutting, increased mechanisation and speed up, demanning and dilution, increasing labour supervision, and extending incentive payment systems remained strong, while "good" management practice dictated that the labour cost element was to be kept pared to the bone. There was little evidence of any widespread movement scientifically to rationalise labour management before 1914 nor seriously to consider the hypothesis that improving the "human factor" in industry could reap considerable benefits in terms of increased productivity and efficiency and therefore lower total production costs.

\section{Industrial health and fatigue in wartime, 1914-8}

There is little evidence to suggest then that up to the first world war the growing volume of theory on the worker from the physiological and psychological standpoint had significantly penetrated British industry. Partly as a consequence of this, serious errors were made in labour management in the early part of the war emergency. The experience of the war, with the demands it brought for strenuous and long maintained effort by the workers on the "home front," exposed the critical lack of knowledge in Britain of the laws governing human health and efficiency, and in particular the need for scientific study of the hours of work, the arrangement of work spells, and other conditions of labour likely to produce the maximum output for the war effort. Voices were raised in protest against the excessively long working hours of munitions workers over 1914-5-often 75-85 a week - and the intensity of work, which, it was argued, was progressively detrimental to workers' health and to the maintenance of output for long, and sustained periods.

In response, the government formed the Health of Munitions Workers Committee (HMWC) in September 1915, "to consider and advise on questions of industrial fatigue, hours of labour and other matters affecting the personal health and efficiency of workers in munitions factories and workshops." ${ }^{15}$ In his War Memoirs David Lloyd . George, then Minister of Munitions, claimed the credit as initiator and founder of the HMWC. This is only partially correct. Walter Fletcher (Secretary of the Medical Research Committee established under the National Insurance Act of 1911) and the research committee on industrial fatigue of the British Association for the Advance ment of Science set up in 1913 (comprising P S Flop rence, B L Hutchins, J H Muirhead, and J W Rams: bottom) played a significant part. In July 1914 the British Association wrote to Fletcher at the MRE suggesting that the National Insurance Commissiof should finance a much more extensive inquiry into. industrial fatigue, as they had discovered "chronic overstrain" as a result of working normal hours anf they argued, "it is obvious that continuous prơ? longation of work beyond the point at which pers manent fatigue sets in is socially uneconomical and must result in waste of strength, health angp efficiency."16 Fletcher approached the Home Office who had appointed Kent in 1913 to investigate thy incidence of fatigue and who, in 1915, was in the prós

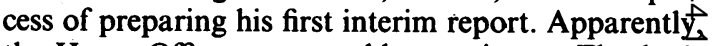
the Home Office gave a cold reception to Fletcher's approach and as a consequence he turned to the Mino istry of Munitions. ${ }^{17}$ In a memo in July 1915 to \& Addison at the ministry, Fletcher pointed out the rep ative backwardness of Britain vis-a-vis the study of industrial fatigue and the penetration of industria medicine and the crucial need to investigate serious industrial health and the physiology of work to max imise productivity for the war effort. Addison replie indicating that Lloyd George agreed to establish sycts a committee and the HMWC was formed in tember $1915 .{ }^{18} \mathrm{P}$ S Florence was commissioned biy the HMWC in October 1915 at a retainer of $£$. month to continue his investigation into industria fatigue at Greenwood and Batley, Engineers, i Leeds. Professor Kent, meanwhile, continued he work for the Home Office and his final report antic $P$ pated, in a number of points, the subsequent finding $\overrightarrow{\hat{S}^{\circ}}$ of the HMWC, though it was not received entirely without criticism. ${ }^{19}$

The HMWC combined representatives of the med? cal profession, academics, labour, employers, the Factory Inspectorate, and the government, and funcs tioned for a little over two years until the end of 1917 . It carried out a series of pioneer investigations under. crudely scientific conditions that were incorporated ip 21 printed memoranda, an interim and final report and a handbook on the health of munitions workerso Its methods were: $(a)$ to gather evidence on working processes and conditions from all interested parties b. establishing commissions of inquiry in several majo industrial towns and munitions producing areas; $(b \Phi$ to visit factories and interview employers, workerss and supervisory staff, and, (c) to commission physt iologists, psychologists, statisticians, medicaf researchers, and industrial hygiene specialists to undertake a series of scientific experiments int

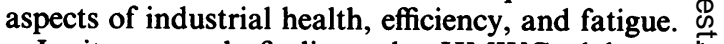

In its research findings the HMWC elaborated significantly on the concept of industrial fatigue arguing that all energy expenditure requires a certaif 
period of recuperation, depending on the strain and intensity of the task, and that overstrain is cumulative, has a permanent effect on the capacity to work, and may, in the long term, result in seriously reduced productivity. ${ }^{20}$ The committee developed a commitment to precise work and output measurement to determine diminished capacity, which it regarded as the most direct and practical indicator of fatigue. One result of the use of output measurement as a guide to fatigue, however, was that the committee earned the suspicion of workers and trade unionists who considered that the object of the HMWC was primarily to speed up production rather than to improve the health and comfort of the workforce. This criticism was also to be subsequently levelled at the Industrial Fatigue Research Board, the government research organisation established on a permanent basis in 1918 to continue the work started by the wartime HMWC.

In its investigation of the relation of working hours to efficiency and health the HMWC presented conclusive statistical evidence indicating that the strain of working excessive hours during the war emergency had seriously retarded productivity and impaired the war effort accordingly. The intensity of overwork and the effect this had on output differed considerably between different occupations and processes. One investigator, $\mathbf{H} \mathbf{M}$ Vernon, however, calculated that for women engaged in "moderately heavy lathe work," a 50 hour working week yielded as good an output as a 66 hour week and a considerably better one than a 75 hour working week. Interestingly, the committee also put forward the hypothesis that worker ca'canny (or go slow) was a sort of physiological self protection, undertaken often quite unconsciously and having beneficial effects on output. The HMWC advised against Sunday working, for the retention of normal holidays, for the introduction of systematic rest pauses, and for working hours to be a maximum of 60 for women and juveniles and 65-7 for men during the war. The government cut hours and abolished Sunday working during the war accordingly.

The HMWC also clearly indicated the direct correlation between good working conditionsespecially adequate light, ventilation, washing, sanitary and safety provision, seating arrangements, and clothing-and productivity and the links between nutrition and efficiency. Environmental factors were recognised as having a crucial impact on workers' health and efficiency and the precise effect of these variables on the output in various processes of munitions manufacture were calculated to find the optimum conditions for maximum productivity. Hence the provision of canteens selling cheap nourishing food was encouraged and by October 1917 some 710 canteens existed in works employing 920000 . The HMWC also recommended increased medical and welfare provision and hundreds of spe- cial welfare supervisors were appointed during the first world war. Factors external to the factory, including transport, housing, and opportunities for recreation also received the attention of the committee, as these were considered to affect health, productivity and, hence, the war effort. ${ }^{21}$

The HMWC constituted, for the first time in British industrial history, a conglomeration of medical and health researchers, combined with industrialists, representatives of labour, academics, and administrators who were working together, under government patronage, to determine by scientific experimentation and analysis the physiological and psychological conditions of labour conducive to maximum efficiency at work and the physical health and well being of the workforce. Admittedly, as A Ineson and D Thom have argued, on certain issues, most notably the case of TNT poisoning, the committee did collude with management to prevent demoralising facts leaking out and to mystify work related health problems. ${ }^{22}$ To dismiss the work of the HMWC as solely a managerial tool, however, is too simplistic and too cynical. It did have a genuine concern to improve workers' health despite the fact that it recognised and, indeed, emphasised the close interconnections between health and productivity. It concluded that provision for workers' health, welfare, and the elimination of industrial fatigue was not only desirable socially, on humanitarian grounds, but essential for the maintenance of industrial efficiency. The war emergency provided the preconditions for the medical researchers' brief phase of influence and for the sort of extensive, scientific investigation into industrial fatigue that some progressive voices had been calling for since the 1890 s. To this extent it was an important watershed in the history of industrial medicine.

\section{Conclusions}

To summarise: it has been argued that there was a deep rooted disregard both for the limitations of human physiology and psychology and for the vast potential for improving worker's health and hence efficiency in British industry before the first world war. Apart from a thin strand of welfarists, the horizons of most employers remained bounded by traditional cost cutting techniques and there is little evidence of any widespread movement to rationalise labour management scientifically or to accept (or even test) the hypothesis that improving the health and fitness of workers could reap considerable benefits in terms of increased productivity. Pioneer attempts to verify the latter hypothesis and to elaborate a concept of industrial fatigue - such as that of William Mather-were severely restricted in their influence by the opposition of organised employers. Whereas private enterprise proved to be parochial and unreceptive, the government registered a some- 
what more positive response, initiating limited changes through the Factory Acts and other ameliorative legislation, adopting the 48 hour working week in several of the ordnance factories, and in 1913 setting up an official Home Office survey into industrial fatigue. Works doctors and nurses were still, however, virtually unknown in British industry outside a few companies, as I H Charley has testified in The Birth of Industrial Nursing (1954). Fatigue and overstrain remained an endemic feature of work.

The prewar government initiatives were considerably extended during 1914-8 by the creation of the HMWC with a remit to investigate industrial fatigue, health, and worker efficiency. The wartime demands for strenuous and long maintained effort brought home the critical lack of knowledge in Britain of the laws governing human efficiency and health at work. The extensive scientific research work of the HMWC staff did much to identify the physiological and psychological conditions conducive to maximum health and worker productivity in the munitions factories. The HMWC also perceived the broader implications of its research beyond the narrow confines of the munitions sector and the war and appealed in its final report for permanent provisions to be made for a research board to investigate health, energy expenditure, and efficiency throughout British industry. Progress along these lines, it was argued in the HMWC memo 7 (1916), was essential if British industry was to maintain its competitiveness:

"False ideas of economic gain, blind to physiological law, must lead, as they led through the nineteenth century, to vast national loss and suffering. It is certain that unless our industrial life is to be guided in the future by the application of physiological science to the details of its management, it cannot hope to maintain its position hereafter among some of its foreign rivals." Government sponsored research activity on industrial fatigue and efficiency continued at a high level through the work of the Industrial Fatigue Research Board (1918-47). Again, however, evidence suggests that the receptivity of British management to the growing body of theory on industrial medicine in the interwar years was relatively poor. This, however, is running beyond the confines of the present paper and is a subject that has been taken up in more detail elsewhere. ${ }^{23}$

\section{References}

1 Weindling P, ed. The social history of occupational health. London: Croom Helm, 1985; Bartrip P, Burman S. The wounded soldiers of industry. Oxford: Clarendon, 1983.
2 Williams A. Life in a railway factory. London: Duckworth, 1915 Tressell RB, Ragged trousered philanthropists. London: Law rence and Wishart, 1955; Clarke A. The effects of the factory system. Littleborough: George Kelsall, 1985. (1st publ 1899): Sherard R, White slaves of England. London: J Bowden, 1897 Blatchford R, Dismal England. London: Walter Scott, 1899.

3 Industrial Fatigue Research Board. Annual report. London: HMSO, 1924:56-7; Wyatt S, Frost L, Stock FGL. Incentives in repetitive work. London HMSO, 1934:56. (Industrial Health Research Board report 69.)

4 Amalgamated Society of Engineers. Annual report. 1895;xiii; Iron Trades Employers' Association. Annual report 1892-3, In: The Engineer. 28 July 1893;96.

5 Mather LE, ed. The right honourable Sir William Mather. Lon- $\overrightarrow{0}$ don: R Cobden-Sanderson, 1925, passim; Mather W. Trade unions and the hours of labour. Tracts on Social Questions. 5; $\vec{\omega}$ 7 May 1892; Mayo E. Human problems of an industrial civilisa- $-\Omega$ tion. New York: Macmillan, 1933.

6 The Engineer. 6 April 1894:289-90.

7 Iron Trades Employers Association. Record. London: ITEA 1900:121-2. The Engineer. 13 April 1894:311; 4 May 1894:371; 17 August 1894:155.

8 PRO Supp 5/31/121/432/705 (Royal Ordnance Factories; reports and correspondence).

9 Stearns P. Lives of labour: work in a maturing industrial society New York: Holmes and Meier, 1975:197-203.

10 Mather W. A reply to some criticisms. Tracts on Social Questions.15 May 1894:4-6.

11 McIvor AJ. Employers' associations and industrial relations in? Lancashire, 1890-1939. (Ph D thesis.) Manchester University,, $\mathbb{D}$ 1983: ch 5; ch 7 (part III); ch 10. Zeitlin J. The labour strategies of British engineering employers, 1890-1922. In: Gospel HF Littler CR, eds. Managerial strategies and industrial relations. London: Heinemann Educational, 1983:25-54; Wigham $+\vec{E} \cdot \overrightarrow{0}$ The power to manage. London: Macmillan, 1973: passim. 음

12 Hard W. What constitutes a fair day's work? System: the maxa: zine of business. New York. A W Shaw, XXV. April 194: 299-302.

13 Oliver T. The physiology and pathology of work and fatigue In: Dangerous trades. London: John Murray, 1902:105-6.

14 Inter Departmental Committee on Physical Deterioration.? Report. Vol I. London: HMSO, 1904:87. (Cmd 2175.)

15 Health of Munition Workers Committee (HMWC). Final report: industrial health and efficiency. London: HMSO, 1918:3. (Cmdō 9065.)

16 British Association Fatigue Committee to the Medical Research Committee (MRC). Letter. 29 July 1914. MRC Archives PFO $18 / 1$.

17 Fletcher W to Newman Sir G. Letter 23 May 1918. MRCD Archives PF 28.

18 Addison C to Fletcher W. Letter 2 Sept 1915; Fletcher W to Addison C. Memorandum 14 July 1915. MRC Archives PF 18.3

19 Stanley Kent A. Second interim report of an investigation of indus trial fatigue by physiological methods. London: HMSO, 1916. (Cmd 8335); Fletcher W to Mather LE. Letter 10 June 1918. MRC Archives PF 27.

20 Health of Munition Workers Committee. Industrial fatigue and its causes. Memorandum 7. London: HMSO, 1916:4. (Cmd 8213.) D

21 Health of Munition Workers Committee. Final report. London:음 HMSO, 1916:127-8.

22 Ineson A. Thom D. TNT poisoning and the employment of $/ \vec{N}$ women workers in the first world war. In: Weindling P, ed. The social history of occupational health. London: Croom Helm, 1985:89-107.

23 McIvor AJ. Manual work, technology and industrial health, $\omega$ 1918-39. Vol 31, No 2. Medical History. London: WellcomeInstitute, 1987:160-89. 